\title{
Seasonal studies of seston lipids in relation to microplankton species composition and scallop growth in South Broad Cove, Newfoundland
}

\author{
C. C. Parrish ${ }^{1,2, *}$, C. H. McKenzie ${ }^{1}$ B. A. MacDonald ${ }^{3}$, E. A. Hatfield ${ }^{1}$ \\ ${ }^{1}$ Ocean Sciences Centre and ${ }^{2}$ Department of Chemistry, Memorial University of Newfoundland, St. John's, Newfoundland, \\ Cana da A1C 5S7 \\ ${ }^{3}$ Department of Biology, University of New Brunswick, Saint John, New Brunswick, Canada E2L. 4L5
}

\begin{abstract}
The concentration and nutritional quality of suspended particulate matter at an experimental scallop aquaculture site on the east coxst of Newfoundland Canada, was determined at 3 depths over an 8 mo sampling period. Lipıd classas and fatty acids were measured chromatographically and the seston components were identified anc quantified by microscopy. These measurements were correlated and then related to the growth of juremile scallops Placopecten magellanicus introduced to the site. The low seston concentrations abserved throughout the year were punctuated by 4 large inputs: the spring diatom bloom, a resuspension event, a summer microzooplankton and nanoflagellate bloom, and a fall increase in zooplankton faecal fellet and heterotrophic dinoflagellate concentrations. The largest inputs of lipids were associated with the resuspension event and the summer bloom. The resuspended particles included the benthic pemate diatom Gyrosigma spp. which contained large lipid globules. High concentrations of polyunsat mated triacylglycerols occurred at this time; more saturated triacylglycerols were prominent in the summer The acyl lipids contained unusually high proportions of the long-chain polyunsaturated fatt $y^{\prime}$ acid 20:4 w6 which was correlated $(p<0.05)$ with the proportion of microzooplankton in the seston. Tt $C_{16}$ fatty acid ratio $16: 1 \omega 7 / 16: 0$, used previously as a diatom biomarker, was strongly correlated $(p<0.01)$ with the proportion of centric diatoms. Scallop growth appeared to be related less to the major aputs of total lipids to the water column and more to the proportion of the essential fatty acid 22:6 33 In the acyl lipids. This fatty acid was associated principally with cryptophytes $(p<0.02)$.
\end{abstract}

KEY WORDS: Lipid classes - Fatty acids - Microalcae - Microzooplankton - Blooms - Resuspension

\section{INTRODUCTION}

Lipids have been extensively used as biomarkers ir marine and freshwater geochemical studies (Saliot et al. 1991, Meyers \& Ishiwatari 1993). Lipids, and espe. cially their component fatty acids, have also been usec in food web studies (Sargent et al. 1987), although with varying degrees of success (Clarke et al. 1987). One of the problems with the use of fatty acids is their sea. sonal and geographic variability in different organ. isms, especially phytoplankton (Mayzaud et al. 1989) Another difficulty associated with the use of fatty acids

\footnotetext{
•E-mail: cparrish@kean.ucs.mun.ca
}

derived from the total lipid extract relates to the different lipid classes which constitute the extract. These classes can be broadly defined into neutral and polar lipids, the former containing storage triacylglycerols and the latter containing membrane glycolipids and phospholipids. These acyl compounds have different functions and structures that may vary between species and in response to environmental conditions. In algae, triacylglycerol synthesis relates directly to environmental conditions (Roessler 1990), while polar lipids have a relatively constant fatty acid composition (Sargent et al. 1987). Thus it can be anticipated that fatty acids derived from neutral lipids may be more indicative of an organism's physiological status while those derived from polar lipids may be more related to 
the organism's taxonomy. It is for this reason that in this study we determined neutral and polar lipid fatty acids in seston of known species composition at different times of the year. To our knowledge this is the first quantitative comparison between microplankton species composition and the proportion of fatty acids in neutral and polar lipids.

The station chosen for the present study contained a natural population of the giant scallop Placopecten magellanicus and was representative of potential aquaculture sites in Newfoundland, Canada. The suitability of a location for growth of natural or introduced marine fauna depends on a variety of environmental factors, not least among which is the quantity and nutritional quality of available food. Lipids are among the more important components of the diet as they supply highly reduced compounds for oxidation, as well as fatty acids whose structure is essential to the normal functioning of animal cells. Members of the family Pectinidae have high proportions of $\omega 3$ and $\omega 6$ polyunsaturated fatty acids in their lipids (Joseph 1982). Animals are unable to synthesize such acids de novo (Gurr \& Harwood 1991) and so scallops must be supplied with them from the natural seston. To investigate the importance of seasonally changing seston composition at this sile, we performed scallop growth measurements in parallel with our seston determinations. We believe this is the first attempt to directly relate the species and chemical composition of natural seston to scallop growth in a cold water environment.

\section{MATERIALS AND METHODS}

Water sampling. Samples were pumped from 3 depths in South Broad Cove, Terra Nova National Park, Newfoundland about every 2 wk from May to December 1991. The overall water depth at the station was $10 \mathrm{~m}$. Water samples for seston analyses were pumped from 3 separate hoses $(12 \mathrm{~mm}$ diameter) secured to a metal frame anchored to the bottom. A self-priming Jabsco pump with a bronze body was used to draw the water through the individual hoses to the surface. The main sampling depth was $20 \mathrm{~cm}$ above bottom, however, on most sampling days, samples were also collected at 50 and $300 \mathrm{~cm}$ above bottom. In all cases duplicate samples were collected. On several days, sampling at a given depth was repeated, sometimes as many as 6 times during that day.

Seston samples. Replicate samples of 0.5 to 6 I were collected on precombusted Whatman GF/C $25 \mathrm{~mm}$ filters under vacuum. Filters for weight determinations were washed with approximately $5 \mathrm{ml}$ of isotonic ammonium formate, added to the last few ml of sample to remove residual salts. Filters were frozen on dry ice and stored in the dark until they were transported back to the laboratory for processing. Filters from each sampling period were separated and used in one of several analyses (2 to 3 filters per analysis) including concentrations of ash free dry weight (AFDW), chlorophyll a (chl a), and lipid classes.

Concentrations of total particulate matter in the seston were determined by weighing filters after they had been dried to constant weight at $55^{\circ} \mathrm{C}$ for $48 \mathrm{~h}$. The filters were then ashed at $450^{\circ} \mathrm{C}$ for $12 \mathrm{~h}$ to determine AFDW Particulate chl a concentrations were determined by extracting filters in $6 \mathrm{ml}$ of $90 \%$ HPLC grade acetone at $-20^{\circ} \mathrm{C}$ for 14 to $16 \mathrm{~h}$. The filters were then pelleted out at approximately $7000 \times \mathrm{g}$ for $5 \mathrm{~min}$ at $4^{\circ} \mathrm{C}$. Chl a concentrations were measured using a Turner Designs Model 10 fluorometer calibrated against a chl a standard (Yentsch \& Menzel 1963).

Seston population analysis. For seston population analyses $200 \mathrm{ml}$ of each seawater sample was preserved in Lugol's and buffered formaldehyde. Components of the seston were identified and enumerated using the Utermöhl (1958) method in which $50 \mathrm{ml}$ of preserved sample was placed in an Utermöhl chamber and allowed to settle. A Zeiss Axiovert 35 inverted microscope was used in the identification, enumeration and measurement of the seston. In most cases one transect across the chamber was counted at $400 \times$ for the cells less than $20 \mu \mathrm{m}$ in diameter. Another count was made covering either half or the entire chamber at $200 \times$ for cells larger than $20 \mu \mathrm{m}$, chains and colonies (Venrick 1978). Microzooplankton, faecal pellets and other identifiable components of the seston were also identified and counted and included in calculations of total cells and total biovolume per litre. Empty diatom frustules and dinoflagellate theca were not counted. From the : Isual counts the number of cells per litre could be calculated from the total area of the chamber used for the $400 \times$ transect by multiplying by the appropriate subsample factor (Hasle 1978). Using the appropriate geometric cell shapes (Rott 1981), the mean cell biovolume for each species and the total biovolume per litre were calculated using an SAS program.

To correlale seston analyses with fatty acid analyses, the seston in the $50 \mathrm{~cm}$ samples was separated into 8 categories: microzooplankton including ciliates, tintinnids (usually greater than $20 \mu \mathrm{m}$ in diameter) and the smaller $(6 \mathrm{~mm})$ choanoflagellates; dinoflagellates including dutotrophs and heterotrophs (ca 12 to $60 \mu \mathrm{m}$ ); prymnesiophytes comprising small ( 2 to $12 \mu \mathrm{m}$ in diameter) spherical nanoflagellates; cryptophytes comprising small (8 to $18 \mu \mathrm{m}$ in length) tear-drop shaped biflagellates centric diatoms ca 12 to $30 \mu \mathrm{m}$ in diameter, connected in long chains; pelagic pennate diatoms which were usually single cells ca $30 \mu \mathrm{m}$ in length; benthic diatoms, especially the large pennate Gyro- 
sigma spp.; and detritus consisting of unidentified organic material. In a couple of samples, pollen grains were included in the biovolume estimates of the benthic diatoms to give a value which would be representative of the contribution of resuspended material to the water column.

Lipid class separation and identification. For lipid analyses, $2 \times 4$ to $6 \mathrm{l}$ of water from each depth was filtered, usually twice in a sampling day. The lipids were extracted from the suspended particulate matter samples using chloroform-methanol 2:1 (v/v). The lipid classes in the extracts were separated on silica gel coated Chromarod-SIII using 4 different solvent systems and then measured in an Iatroscan MK V (Parrish 1987). The first solvent system was hexane/diethyl ether/formic acid (99:1:0.05 by vol.). After a first 25 min and a second 20 min development, the bands were detected by scanning in the Iatroscan to the position occupied by ketone. After a 40 min development in the second solvent system of hexane/diethyl ether/ formic acid $(80: 20: 0.1$ by vol.), the bands were scanned to the position occupied by diacylglycerol. The remaining fraction was developed twice in $100 \%$ acetone for $15 \mathrm{~min}$ and then twice in chloroform/ methanol/water (50:40:10 by vol.) for $10 \mathrm{~min}$. The bands were detected by completely scanning the Chromarods.

The 3 chromatograms were combined using ' $T$ data scan software' (RSS, Inc, CA, USA). The signal detected in millivolts was converted to peak areas which were quantified using lipid standards (Sigma, St. Louis, MO, USA).

Derivatization and analysis of fatty acids. About $1 \mathrm{mg}$ of extracted lipid from $50 \mathrm{~cm}$ samples collected from May to October 1991 was separated into neutral and polar fractions on activated Florisil and derivatized to fatty acid methyl esters (FAMEs) using $\mathrm{BF}_{3} / \mathrm{MeOH}$. Iatroscan analysis showed that Florisil chromatography gave a good separation between neutral and polar lipids. It also gave good recoveries of all major classes except free fatty acids in the neutral lipids and phosphatidyl ethanolamine in the polar lipids which were significantly retained by the column. The sample and $2 \mathrm{ml}$ of methylating reagent were heated at $80^{\circ} \mathrm{C}$ for $1 \mathrm{~h}$. One $\mathrm{ml}$ of double distilled water was added followed by $4 \mathrm{ml}$ hexane. The FAMEs were obtained by withdrawing the organic layer after centrifuging the mixture at $1000 \mathrm{rpm}(125 \times \mathrm{g})$ for $5 \mathrm{~min}$.

The FAMEs were measured in a Varian Model 3400 gas chromatograph (Varian, CA) using a fused silica capillary column (30 $\mathrm{m} \times 0.32 \mathrm{~mm}$ i.d.) coated with Omegawax ${ }^{\text {TM }} 320$ (Supelco, PA, USA). Peaks were identified by comparing their retention times with those of FAME standards (Supelco Canada, ON, Canada).
Triacylglycerol carbon number distribution. To determine the triacylglycerol carbon number distribution, the neutral ljpid fraction which was separated from the total lipids on an activated Florisil column was analyzed in a Varian gas chromatograph with a $7.4 \mathrm{~m}$ DB5 column (J\&W Scientific, CA, USA). The neutral lipids were injected onto the column through a Septum Programmable Injector (Varian) and the column temperature was programmed to rise from 62 to $340^{\circ} \mathrm{C}$.

Scallop growth studies. Two hundred sea scallops Placopecten magellanicus, approximately $40 \mathrm{~mm}$ in shell height, were ear hung on frames $(1.2 \times 1.2 \mathrm{~m})$ made of $25 \mathrm{~mm}$ P.rC. Replicate frames were suspended horizontally at heights of 20,50 and $300 \mathrm{~cm}$ above bottom. Shell heights of all scallops were recorded monthly to the nearest $0.1 \mathrm{~mm}$ using vernier calipers, until December 1991. Approximately every month from June until November 1991, 10 randomly selected scallops were removed from the frame to determine mean dry weight of the soft body parts. Scallops were frozen on dry ice, transported to the laboratory, and tissues dissected from the shell and lyophilized at $-60^{\circ} \mathrm{C}$

\section{RESULTS}

\section{Seston chlorophyll and organic weight}

Seston concentrations of chl a and AFDW were generally low but were punctuated by periods of much higher concentrations (Fig. 1). There was a 10- to 25fold difference between the highest and lowest concentrations measured in the time course: 0.23 to $2.50 \mathrm{mg} \mathrm{l}^{-1}$ for organic weight and 0.12 to $2.97 \mathrm{\mu g} \mathrm{l}^{-1}$ for chl $a$.

The average concentration of chl a over the 8 mo sampling period ranged from $0.65 \pm 0.20 \mathrm{\mu g} \mathrm{l}^{-1}$ (mean \pm SEM) at $300 \mathrm{~cm}$ above bottom ( $\mathrm{n}=13 \mathrm{sampling}$ days) to $0.70 \pm 0.11 \mu \mathrm{g} \mathrm{l^{-1 }}$ at $50 \mathrm{~cm}(\mathrm{n}=14$ sampling days $)$. There was no significant difference in the seasonal average concentrations between any of the depths $(p>$ 0.8 ); however, the time courses for the 3 depths showed differences in the timing and magnitude of maxima over the season. The highest $\mathrm{chl}$ a concentration measured at $300 \mathrm{~cm}$ occurred in May on Day 136, while for the $20 \mathrm{~cm}$ samples the maximum concentration occurred in July on Day 210 (Fig. 1a).

The average concentration of AFDW ranged from $0.78 \pm 0.17 \mathrm{mg} \mathrm{l}^{-1}$ at $300 \mathrm{~cm}$ ( $\mathrm{n}=15$ sampling days) to $0.99=0.09 \mathrm{mg} \mathrm{l}^{-1}$ at $20 \mathrm{~cm}$ ( $\mathrm{n}=18$ sampling days $)$. Again there was no significant difference in the seasonal averages $(p>0.2)$, but there were differences in the time courses Fig. 1b). Most notably there was a large peak in AFDW at $300 \mathrm{~cm}$ in September on Day 261. 

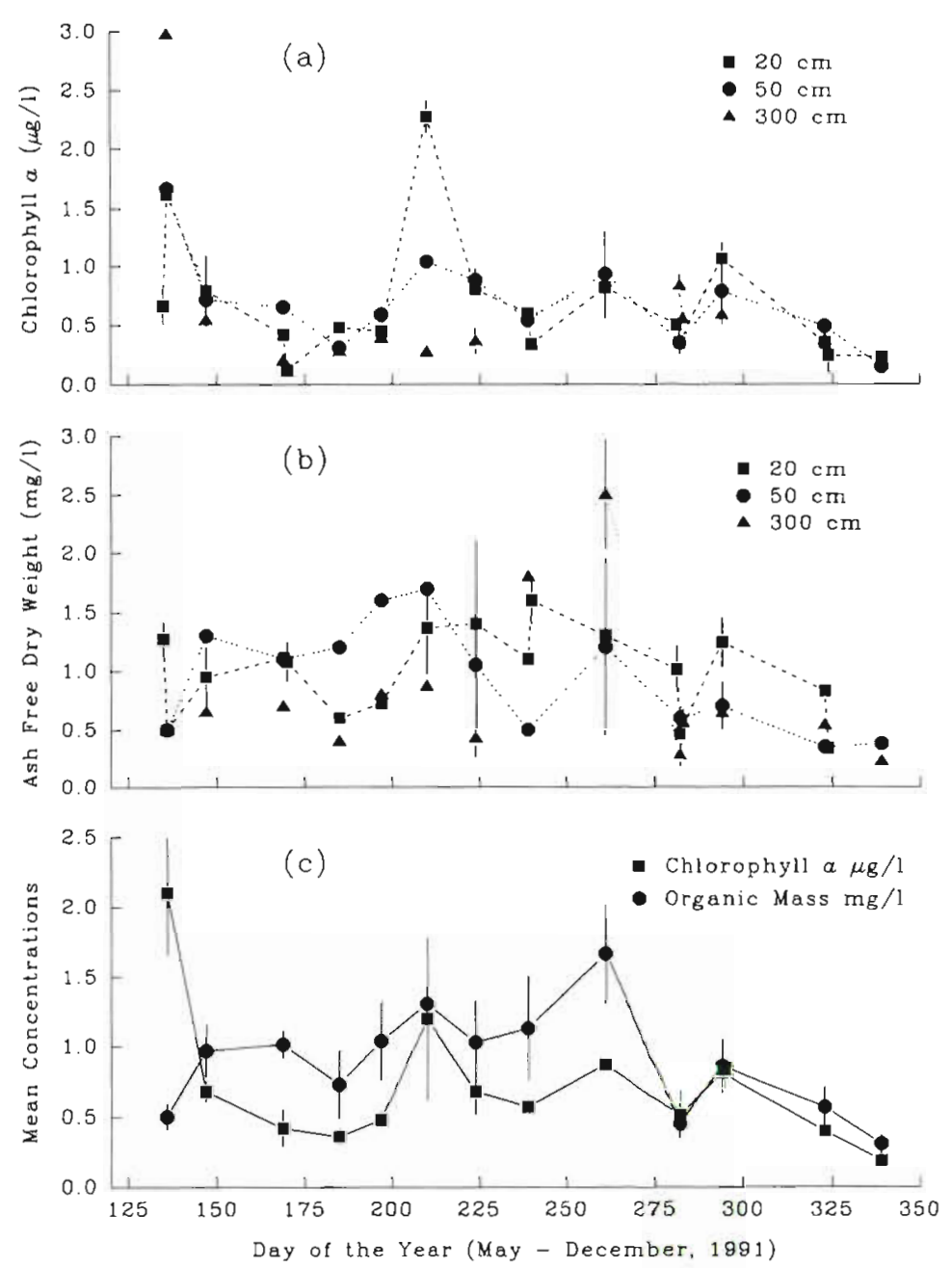

Fig. 1. Concentrations of chlorophyll a ( $\mathrm{chl}$ a) and ash free dry weight (AFDW) in South Broad Cove, Newfoundland, Canada. (a) Chl a. Error bars indicate where duplicate samples were taken at more than 1 time on a sampling day. For 20 and $300 \mathrm{~cm}$ samples, error bars are SEM for up to 5 different sampling times over a period of up to $5.5 \mathrm{~h}$. Error bars for $50 \mathrm{~cm}$ data indicate the range for duplicate samples taken twice over a period of up to 2.5 h. (b) AFDW. Error bars indicate where duplicate samples were taken at more than 1 time on a sampling day. For 20 and $300 \mathrm{~cm}$ samples, error bars are SEM for up to 6 different sampling times over a period of up to $4.5 \mathrm{~h}$. Error bars for $50 \mathrm{~cm}$ data indicate the range for duplicate samples taken twice over a period of up to $2.5 \mathrm{~h}$. (c) Mean $\pm \operatorname{SEM}(\mathrm{n}=3$ depths) of chl $a$ and AFDW concentrations determined for the same sampling day
The overall trends for the bottom $300 \mathrm{~cm}$ of the water column in South Broad Cove are shown in Fig. 1c which gives the mean \pm SEM of concentrations of chl a and AFDW from the 3 depths over the sampling period. The highest average chl a concentration was measured on Day 136 of that year. A second peak occurred near the middle of the time course on Day 210 . The mean concentration of organic matter, as determined by ashing, increased until Day 169 in June, after which it declined. There was then another peak coincident with the secondary chl a peak; a final peak, the largest in the time series, occurred in September.

\section{Seston populations}

Seston biovolume concentrations were similar to chlorophyll and organic weight concentrations in that they were generally low throughout the season, except for occasional periods of much higher concentrations. Biovolume concentrations ranged from near zero to 7.1 $\times 10^{8} \mu \mathrm{m}^{3} \mathrm{1}^{-1}$ (Fig. 2). Maxima and minima in seston biovolume estimates (Fig. 2) coincided, for the most part, with maxima and minima in concentrations of chl a and organic mass (Fig. 1). This was especially true among the $20 \mathrm{~cm}$ samples. Samples taken at the middle depth were further separated into categories in order to compare the relative contributions of the different seston groups (Fig. 3).

The first peak in chl a (Fig. 1c) in mid-May on Day 136 was caused by a bloom of chain-forming centric diatoms (Figs, $2 \& 3$ ). The most abundant species during the spring diatom bloom were Chaetoceros socialis, Thalassiosira nordenskioldii, Coscinodiscus spp., and Detonula spp.; however, $98 \%$ of the biovolume was contributed by the large centric species $T$. nordenskioldii and several sizes of Coscinodiscus. Thalassiosira in particular contained large amounts of chlorophyll.

By mid-June on Day 169, seston microscopic analysis indicated that the spring diatom increase had ended and that $93 \%$ of the seston (numerically) was com- 
posed of smaill flagellates, particularly prymnesiophytes, Over $70 \%$ of the biovolume at this time was contributed by the naked ciliates Hesodinium rubrum and Stroblidinium spp. (Fig. 3). Large benthic pennate diatoms, including Gyrosigma spp., were als found in these samples. These large diatorns contained large lipid storage globules so that Gyrosigma would have contributied a disproportionate amount to the mentral lipid composition of these samples. The samples also contained diatom fnutules, spores, cysts and debris, which suggests a resuspension event had recemilly occurred.

Microzooplankton (ciliates and tintinnids) and small manoflagellates caused the second peak in mean organic matter and chl $a$ in July on Day 210. Ciliates accounted for $61 \%$, of the seston with Mesodinium rubrum mumbering all other ciliates by 14:1. Although the flagellates were numerically dominant throughout the summer, it was only in samples from late July that they contributed significantly $(29 \%)$ to the biovolume (Fig. 3). At this time the nanoflagellate population was composed of prymnesiophytes and cryptophytes. The contribution by ciliates continued to decline throughout the remainde- of the summer and fall, while the presence of faere. pellets, zooplankton and other seston increased. Faecal pellets were significant contributors to our sestor samples probably because of our use of a pump to sample.

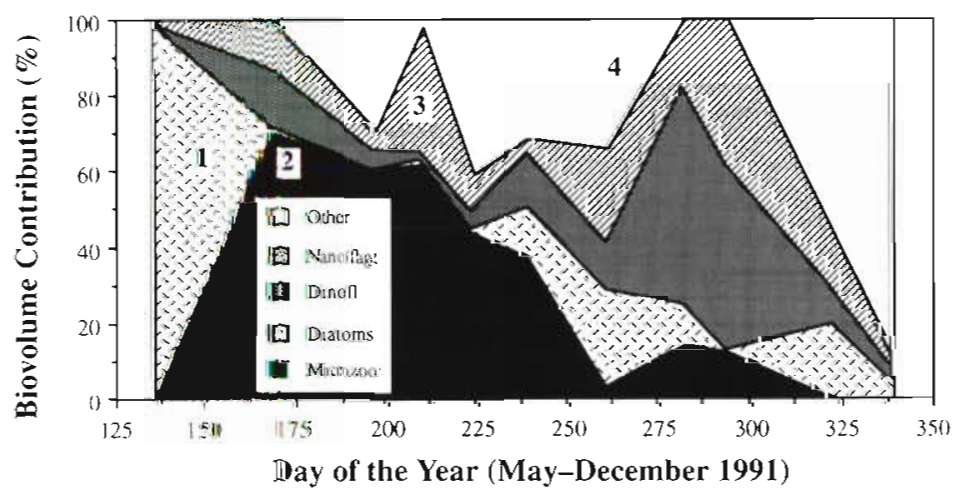

Fig. 3. Biovolume.ptraportions (\% total biovolume) of different groups in the $50 \mathrm{~cm}$ samples Microzoo: several species of ciliates and tintinnids and several specius of bacterivorous choanoflagellates. Diatoms: centric and pennate speries. Dinofl: autotrophic and heterotrophic species of dinoflagellate. Miarioflag: all 2 to $20 \mu \mathrm{m}$ flagellates, primarily prymnesiophytes, cryptopolytes and some prasinophytes. Other: remaining seston, e.g. faecal pellets and zooplankton. 1: Spring diatom bloom. 2: Benthic diatoms, empty frustules, spores and cysts indicate resuspension event. 3 icliate and flagellate bloom. 4: Fall diatom bloom
Zooplankton faecal pellets, diatoms and heterotrophic (nonphotosynthesizing) dinoflagellates were associated with the largest peak in organic matter in the time course on Day 261 . The $50 \mathrm{~cm}$ sample contained $34 \%$ faecal pellets and $23 \%$ pennate diatoms, primarily Nitzschia delicatissima, as part of the fall diatom bloom. The nanoflagellates were composed primarily of prymnesiophytes $(18 \%)$; however, there was an increase in cryptophytes $(7 \%)$ and quadriflagellated prasinophytes in these samples. These samples also contained 13\% dinollagellates suggesting the beginning of a bloom.

In October the seston was dominated by heterotrophic and autotrophic dinoflagellates, primarily species of Dinophysis, Gymnodinium, Gyrodinium and later Protoperidinium. November and December samples contained large numbers of faecal pellets which made up most of the seston; however, some centric diatom species of Coscinodiscus were also present (19\%)

\section{Total lipids and lipid classes}

The complete Iatroscan-determined lipid class composition of suspended particulate matter collected at $300 \mathrm{~cm}$ above bottom is shown in Fig. 4. The largest chromatographic peak is that of the internal standard added to the extract to aid in quantification. The lipid classes determined in the fixst Chromarod 


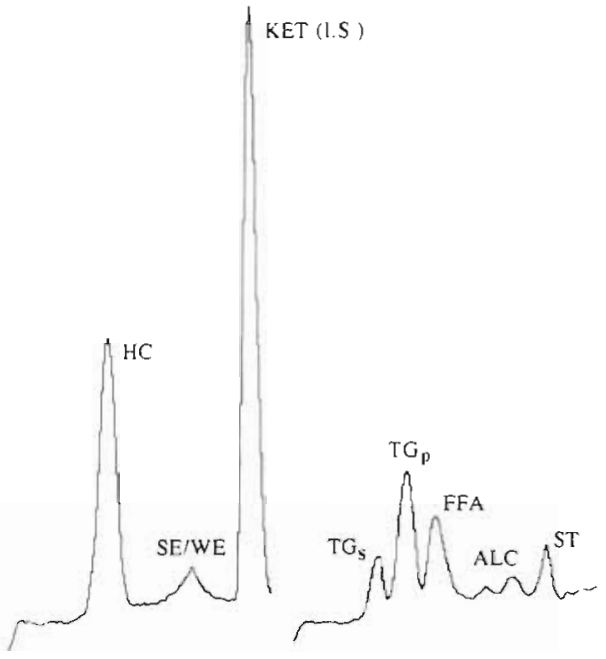

scan were hydrocarbon and steryl and wax esters. In the second scan the triacylglycerol peak was split into species containing mainly saturated fatty acids $\left(\mathrm{TG}_{\mathrm{s}}\right)$ and those containing mainly polyunsaturated fatty acids $\left(\mathrm{TG}_{\mathrm{p}}\right)$. Free fatty acids, aliphatic alcohols and sterols were also determined in the second scan. The final, complete scan revealed the major components in the lipids, the acetone-mobile polar lipids and the phospholipids.

Fig. 5a shows the mean \pm SEM total lipid and acetone-mobile polar lipid concentrations for the 3 depths. The acetone-mobile polar lipid was, on average, the major component of the total lipids at all 3 depths (Table 1). There were 2 maxima in the concentrations of total lipids, one in June on Day 169, which coincided with the first peak in AFDW, and one in July on Day 210, which coincided with the second chl a peak. The highest average concentration of acetone-mobile polar lipid was also observed on Day 210 (Fig. 5a).

The concentrations of total lipids were higher in the first half of the time course than in the second half, especially at $20 \mathrm{~cm}$ (Fig 6a). The proportions of the major components of the lipids, the polar lipids (Fig. 6b, c), showed a reciprocal trend. The membrane associated phospholipids were prominent in the first half of the time course while the acetone-mobile polar lipids, which include glycolipids, were prominent in the second half.

Iatroscan-measured chromatograms of the neutral lipid classes were very different in different months. Fig. 7 shows 3 Chromarod scans of samples collected at 20 and $50 \mathrm{~cm}$ above bottom. The figure indicates a strong
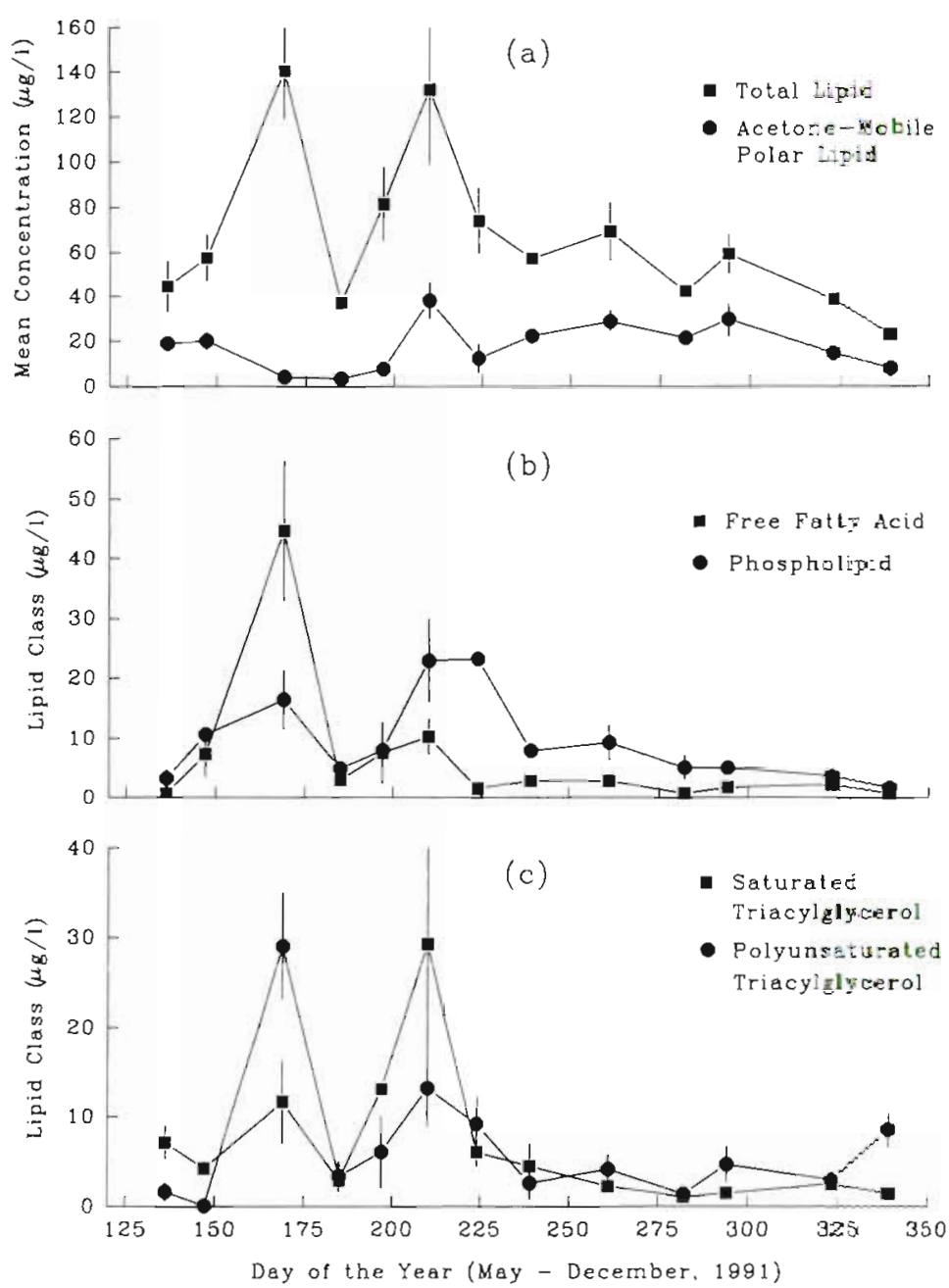

Fig. 5. Seston lipid concentrations in South Broad Cove in 1991 Data are mean \pm SEM for the 3 sampling depths. (a) Total lipid and acewnemobile polar lipid. (b) free tatty acid and phospholipid, (c) polyurisiturated and more saturated triacylglycerol
Fig. 4. Complete lipid class composition of suspended particulate matter collected at $300 \mathrm{~cm}$ above bottom in South Broad Cove in November. : hydrocarbon; SE/WE: steryl and wax esters: saturated triacylglyceroli $\mathrm{TG}_{\mathrm{p}}$ : polyunsacurated triacylglycerol; FFA: free fatty acid; $A L C$ : aliphatic alcohol: ST: sterol (alicyclic a cohol); AMPL: acetone-mobile polar lipid; PL: phospholipid 
Table 1. Surmary data for lipid classes in seston samples collected from South Broad Cove, Newfoundland, Canada, from 16 May to 5 December 1991. Data are mean \pm SEM $(n=12$ to 18 sampling days). Abbreviations explained in Fig. 4 legend

\begin{tabular}{|c|c|c|c|}
\hline $\begin{array}{l}\text { Lipid } \\
\text { class }\end{array}$ & $\begin{array}{l}\text { Height above bottom } \\
\qquad(\mathrm{cm})\end{array}$ & $\mu \mathrm{g} \mathrm{l}^{-1}$ & $\%$ \\
\hline $\mathrm{HC}$ & $\begin{array}{r}20 \\
50 \\
300\end{array}$ & $\begin{array}{c}16.9 \pm 3.0^{\circ} \\
13.5 \pm 2.6 \\
9.3 \pm 1.4^{\circ}\end{array}$ & $\begin{array}{l}23.8 \pm 3.1 \\
23.8 \pm 4.9 \\
19.0 \pm 2.1\end{array}$ \\
\hline SE/WE & $\begin{array}{r}20 \\
50 \\
300\end{array}$ & $\begin{array}{l}1.8 \pm 0.6 \\
1.6 \pm 0.5 \\
2.8 \pm 1.4\end{array}$ & $\begin{array}{l}2.9 \pm 0.9 \\
2.7 \pm 1.0 \\
2.5 \pm 0.8\end{array}$ \\
\hline$T_{\mathrm{s}}$ & $\begin{array}{r}20 \\
50 \\
300\end{array}$ & $\begin{array}{l}7.9 \pm 3.2 \\
7.0 \pm 2.1 \\
3.9 \pm 0.9\end{array}$ & $\begin{array}{l}8.9 \pm 1.7 \\
8.6 \pm 1.7 \\
8.3 \pm 2.2\end{array}$ \\
\hline $\mathrm{TG}_{\mathrm{p}}$ & $\begin{array}{r}20 \\
50 \\
300\end{array}$ & $\begin{array}{l}7.1 \pm 2.1 \\
6.5 \pm 2.3 \\
5.5 \pm 2.0\end{array}$ & $\begin{array}{l}8.2 \pm 1.6 \\
8.6 \pm 1.9 \\
9.1 \pm 3.6\end{array}$ \\
\hline FFA & $\begin{array}{r}20 \\
50 \\
300\end{array}$ & $\begin{array}{l}4.7 \pm 1.7 \\
9.1 \pm 5.1 \\
2.4 \pm 0.6\end{array}$ & $\begin{array}{l}6.0 \pm 1.4 \\
8.2 \pm 2.9 \\
4.4 \pm 1.1\end{array}$ \\
\hline ALC & $\begin{array}{r}20 \\
50 \\
300\end{array}$ & $\begin{array}{l}2.1 \pm 0.4 \\
1.8 \pm 0.4 \\
1.5 \pm 0.3\end{array}$ & $\begin{array}{l}3.5 \pm 0.7 \\
2.8 \pm 0.7 \\
2.7 \pm 0.4\end{array}$ \\
\hline ST & $\begin{array}{r}20 \\
50 \\
300\end{array}$ & $\begin{array}{l}0.9 \pm 0.1 \\
0.9 \pm 0.2 \\
1.0 \pm 0.2\end{array}$ & $\begin{array}{l}1.4 \pm 0.2 \\
1.4 \pm 0.2 \\
1.7 \pm 0.2\end{array}$ \\
\hline $\mathrm{DG}$ & $\begin{array}{r}20 \\
50 \\
300\end{array}$ & $\begin{array}{l}1.5 \pm 0.3 \\
1.6 \pm 0.5 \\
1.2 \pm 0.4\end{array}$ & $\begin{array}{l}2.6 \pm 0.6 \\
2.3 \pm 0.5 \\
2.2 \pm 0.6\end{array}$ \\
\hline AMPL & $\begin{array}{r}20 \\
50 \\
300\end{array}$ & $\begin{array}{l}19.2 \pm 2.9 \\
16.2 \pm 2.9 \\
17.3 \pm 3.8\end{array}$ & $\begin{array}{l}31.2 \pm 3.3 \\
29.5 \pm 5.2 \\
34.6 \pm 5.0\end{array}$ \\
\hline PL & $\begin{array}{r}20 \\
50 \\
300\end{array}$ & $\begin{array}{l}9.0 \pm 2.2 \\
8.9 \pm 2.1 \\
8.4 \pm 1.8\end{array}$ & $\begin{array}{l}11.5 \pm 1.8 \\
12.2 \pm 2.5 \\
15.5 \pm 2.8\end{array}$ \\
\hline Total & $\begin{array}{r}20 \\
50 \\
300\end{array}$ & $\begin{array}{l}74.1 \pm 11.3 \\
66.9 \pm 11.3 \\
52.1 \pm 6.8\end{array}$ & \\
\hline LI $(\%]$ & $\begin{array}{r}20 \\
50 \\
300\end{array}$ & $\begin{array}{r}13.5 \pm 2.0 \\
15.7 \pm 3.6 \\
9.2 \pm 1.6\end{array}$ & \\
\hline \multicolumn{4}{|c|}{$\mathrm{p}=0.033$} \\
\hline
\end{tabular}

seasonality in the input of triacylglycerols containing more highly unsaturated fatty acids and those containing more saturated fatty acids. The maxima in the average concentrations of these triacylglycerols occurred af different times (Fig. 5b). The highest average concentration of the more highly unsaturated triacylglycerols occurred in June on Day 169, when Gyrosigma! spp. and Mesodinium rubrum were prominent in the samples, while that of the triacylglycerols containing more saturated fatty acids occurred in July on Day 210. when microzooplankton and nanoflagellates were prominent.
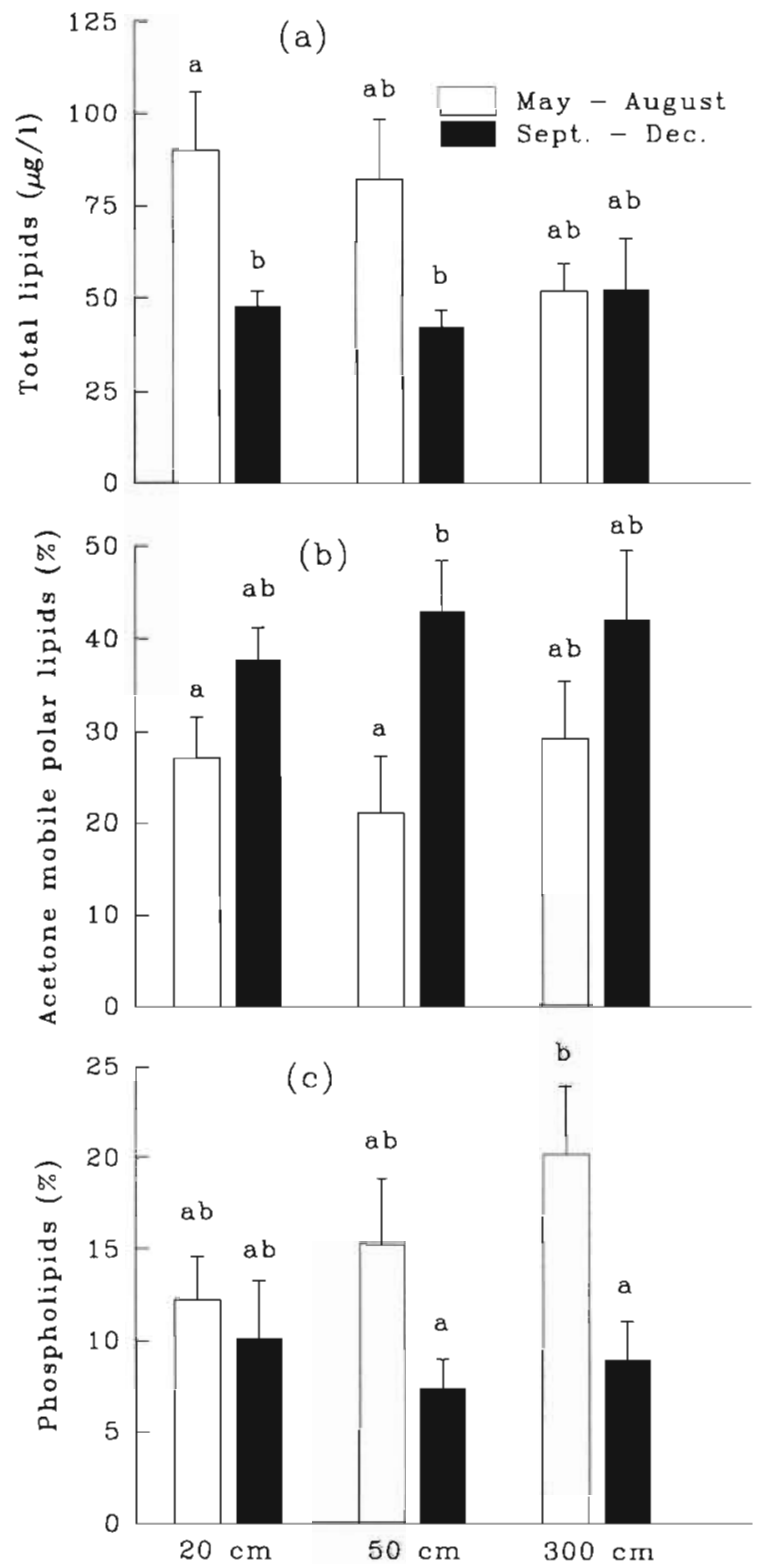

Fig. 6. Seasonal averages in lipid concentrations and lipid class proportions for 3 depths in South Broad Cove in 1991. Means not sharing the same letter are significantly different $(p<0.05)$. (a) Total lipid concentrations, (b) proportion of ace-

tone-mobile polar lipid, (c) proportion of phospholipid

\section{Fatty acids in neutral and polar lipids}

Thirty-eight different fatty acids were identified in $50 \mathrm{~cm}$ samples from South Broad Cove (Table 2). Most were positively identified by comparison of retention times with standards; however, some (designated '?') could only be identified by comparison with the literature. Fatty acids are distinguished from each other by differences in chain length, the degree of unsaturation 


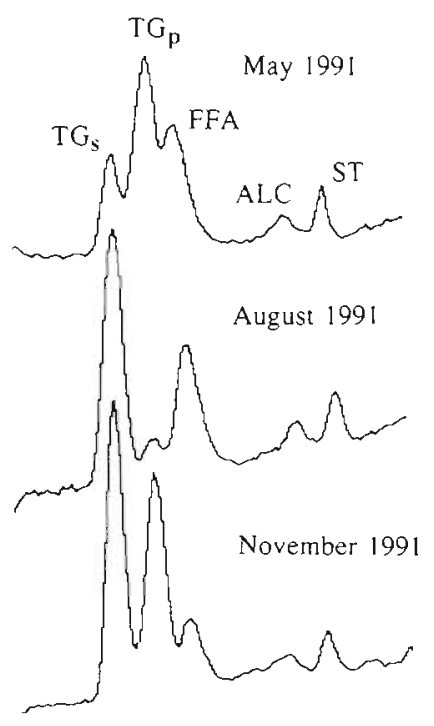

Fig. 7. Three Chromarod scans of neutral lipid classes in suspended particulate matter collected at 20 and $50 \mathrm{~cm}$ above bottom in South Broad Cove in 1991

and the location of the first double bond in a series. Thus fatty acids are designated by the ratio of fatty acid carbon atoms (e.g 22) to carbon-carbon double bonds (e.g. 6 in 22:6), and the position of the first double bond with respect to the methyl end of the fatty acid (e.g. $\omega 3$ in 22:6w3). It was this particular fatty acid that was the only one present in significantly higher proportions later in the time course (Fig. 8).

In a comparison between the proportion of total polyunsaturated fatty acids determined by gas chromatography (GC) on the polar column (Table 2) and the proportion of $\mathrm{TG}_{\mathrm{p}}$ in the total neutral acyl lipids [those containing fatty acids: steryl and wax esters (SE/WE), methyl esters (ME), triacylglycerols (TG), free fatty acids (FFA), diacylglycerols (DG)] the 2 determinations were correlated $(r=0.61, p<0.01, n=20)$ and there was no significant difference between the means $(p=0.1)$.

\section{Triacylglycerol carbon number distributions}

Analysis of $50 \mathrm{~cm}$ neutral lipid fractions on a non-polar column showed that the number of acyl carbons in the triacylglyc-
Table 2. Fatty acids (wt \%) in $50 \mathrm{~cm}$ samples from South Broad Cove, mear \pm SEM ( $\mathrm{n}=8$ samplıng days from May to October 1991), and calculated from Mayzaud et al. (1989) for Bedford Basin, Nova Scotia, Canada ( $\mathrm{n}=14 \mathrm{sam}$ pling days from March to August 1976)

\begin{tabular}{|c|c|c|c|}
\hline Fatty acids & Neutral lipids & Polar lipids & Mayzaud et al \\
\hline 13:0 & $\operatorname{tr}$ & $1.0 \pm 0.4$ & - \\
\hline 14:0 & $6.0 \pm 1.2$ & $6.5 \pm 0.8$ & $9.8 \pm 0.9$ \\
\hline $15: 0$ & $0.6 \pm 0.2$ & $1.3 \pm 0.1$ & $1.1 \pm 0.1$ \\
\hline Iso $16: 0$ & $1.1 \pm 0.3$ & tr & $0.3 \pm 0.05$ \\
\hline $16: 0$ & $31.1 \pm 2.8$ & $27.9 \pm 1.8$ & $19.4 \pm 1.1$ \\
\hline 18:0 & $7.5 \pm 0.9^{\circ}$ & $14.3 \pm 2.9^{\circ}$ & $4.3 \pm 0.4$ \\
\hline 19:0 & $0.2 \pm 0.1$ & & $0.1 \pm 0.02$ \\
\hline 20:0 & $1.1 \pm 0.3$ & $2.1 \pm 1.0$ & $0.2 \pm 0.02$ \\
\hline $21: 0$ & $0.1 \pm 0.0$ & $\operatorname{tr}$ & $0.1 \pm 0.02$ \\
\hline $22: 0$ & $0.9 \pm 0.5$ & $3.6 \pm 1.4$ & $0.5 \pm 0.04$ \\
\hline $24: 0$ & $0.5 \pm 0.2$ & $0.8 \pm 0.4$ & $0.2 \pm 0.05$ \\
\hline Total saturated FA & $49.0 \pm 3.3$ & $57.4 \pm 2.9$ & $38.6 \pm 2.0$ \\
\hline $16: 1 \omega 9 ?$ & $1.8 \pm 0.5$ & $1.5 \pm 0.7$ & $1.4 \pm 0.2$ \\
\hline $16: 1 \omega^{7}$ & $2.8 \pm 1.0^{\circ}$ & $6.8 \pm 1.7^{\circ}$ & $13.7 \pm 2.2$ \\
\hline $18: 1 \omega 9$ & $9.4 \pm 2.3$ & $9.1 \pm 1.0$ & $7.3 \pm 1.0$ \\
\hline $18: 1 \omega 7$ & $1.9 \pm 0.9$ & $2.2 \pm 0.3$ & $2.3 \pm 0.2$ \\
\hline $18: 1 \omega 5 ?$ & $1.4 \pm 0.6$ & $1.1 \pm 0.3$ & $0.3 \pm 0.04$ \\
\hline $20: 1 \omega 9$ & $6.1 \pm 1.4^{\circ}$ & $1.7 \pm 0.6^{\circ}$ & $0.8 \pm 0.2$ \\
\hline $20: 1 \omega 7 ?$ & $0.4 \pm 0.2$ & $0.2 \pm 0.1$ & $0.3 \pm 0.1$ \\
\hline $22: 1 \omega 11$ & $1.8 \pm 0.9$ & $1.1 \pm 0.8$ & $0.7 \pm 0.3(+\omega 131$ \\
\hline $22: 1 \omega 9$ & $\operatorname{tr}$ & $2.4 \pm 1.3$ & $0.9 \pm 0.4$ \\
\hline $24: 1$ & $3.0 \pm 2.5$ & $0.2 \pm 0.2$ & $1.1 \pm 0.3$ \\
\hline Total monoenoic FA & $28.8 \pm 4.2$ & $26.3 \pm 2.9$ & $29.3 \pm 1.9$ \\
\hline $16: 2 \omega 6 ?$ & $2.0 \pm 0.9$ & $0.6 \pm 0.2$ & $0.2 \pm 0.1$ \\
\hline $18: 2 \omega 6$ & $3.2 \pm 0.7$ & $3.6 \pm 0.6$ & $2.7 \pm 0.4$ \\
\hline $20: 206$ & $2.5 \pm 1.0$ & $0.8 \pm 0.5$ & $0.1 \pm 0.02$ \\
\hline Total dienoic FA & $7.7 \pm 1.2^{\cdot}$ & $5.1 \pm 1.1^{\circ}$ & $4.0 \pm 0.3$ \\
\hline $18: 3 \omega 3$ & $2.8 \pm 1.0$ & $1.1 \pm 0.5$ & $2.0 \pm 0.5(+\omega 4)$ \\
\hline Total trienoic FA & $2.8 \pm 1.0$ & $1.1 \pm 0.5$ & $3.7 \pm 0.5$ \\
\hline $16: 4 \omega 3 ?$ & $\operatorname{tr}$ & $0.4 \pm 0.3$ & $0.9 \pm 0.3$ \\
\hline $16: 4 \omega 1 ?$ & $0.8 \pm 0.7$ & & $2.9 \pm 0.4$ \\
\hline $18: 4 \omega 3$ & $2.3 \pm 0.7$ & $2.2 \pm 1.1$ & $4.5 \pm 0.7$ \\
\hline $18: 4 \omega 1 ?$ & $0.8 \pm 0.6$ & $0.2 \pm 0.2$ & \\
\hline $20: 4 \omega 6$ & $2.0 \pm 1.2$ & $0.3 \pm 0.2$ & $0.4 \pm 0.1$ \\
\hline $20: 4 \omega 3 ?$ & $0.7 \pm 0.4$ & tr & $0.3 \pm 0.04$ \\
\hline $22: 4 \omega 6$ & $0.5 \pm 0.3$ & tr & \\
\hline $22: 4 \omega 3 ?$ & $1.3 \pm 0.7$ & $0.4 \pm 0.2$ & \\
\hline Total tetraenoic FA & $8.8 \pm 3.1$ & $3.7 \pm 1.3$ & $7.7 \pm 0.8$ \\
\hline $18: 5 \omega 3 ?$ & & $0.2 \pm 0.1$ & $2.9 \pm 0.6$ \\
\hline $20: 5 \omega 3$ & $1.0 \pm 0.3$ & $1.5 \pm 0.6$ & $6.9 \pm 0.8$ \\
\hline $21: 503$ & $0.8 \pm 0.7$ & tr & $0.2 \pm 0.1$ \\
\hline $22: 503$ & $0.3 \pm 0.2^{\bullet}$ & $3.0 \pm 1.3^{\circ}$ & $0.6 \pm 0.2$ \\
\hline Total pentaenoic FA & $2.1 \pm 0.8$ & $4.7 \pm 1.2$ & $10.3 \pm 1.1$ \\
\hline $22: 6(1) 3$ & $1.0 \pm 0.4$ & $1.5 \pm 0.4$ & $5.0 \pm 0.8$ \\
\hline$\Sigma C_{16} / \Sigma C_{18}$ & $2.2 \pm 0.5$ & $1.3 \pm 0.1$ & $1.8 \pm 0.2$ \\
\hline $16: 1 \omega 7 / 16: 0$ & $0.1 \pm 0.1^{\circ}$ & $0.2 \pm 0.1^{\circ}$ & $0.8 \pm 0.1$ \\
\hline $\mathrm{P} / \mathrm{S}$ & $0.5 \pm 0.1$ & $0.3 \pm 0.1$ & $0.5 \pm 0.1$ \\
\hline$\sum \omega 6 / \sum \omega 3$ & $1.5 \pm 0.6$ & $0.6 \pm 0.1$ & $0.2 \pm 0.02$ \\
\hline \multicolumn{4}{|c|}{$\begin{array}{l}\text { ?: tentative identification based on the literature (e.g. Ackman } 1986) \\
\mathrm{p}=0.001 \text { to } 0.048\end{array}$} \\
\hline
\end{tabular}




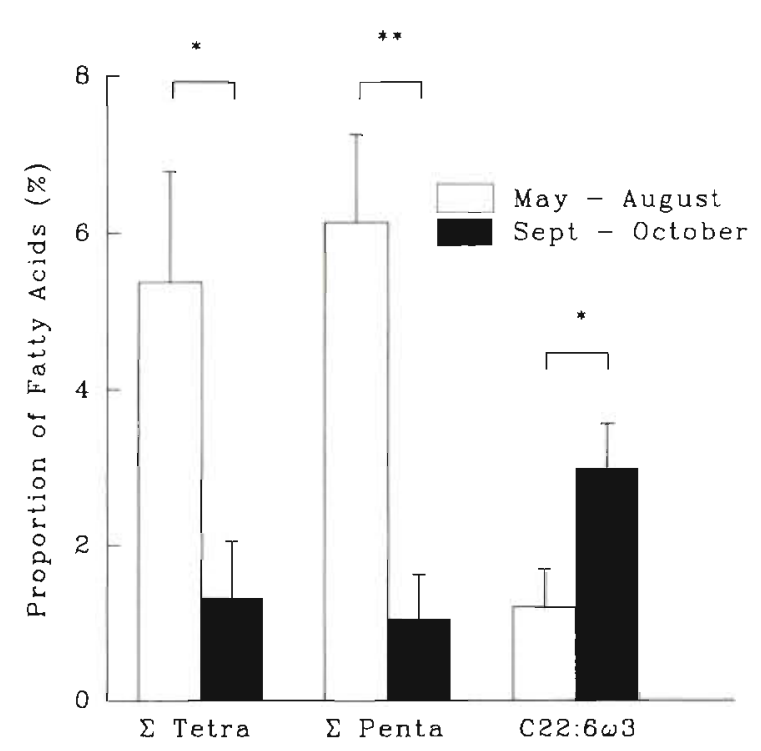

Fig. 8. Seasonal averages of polyunsaturated fatty acid proportions of total fatty acids in particulate matter polar lipids sampled from $50 \mathrm{~cm}$ above bottom in South Broad Cove in 1991. Data are shown for total tetraenoic fatty acids, total pentaenoic fatty acids and the only hexaenoic fatty acid identified in the samples. " $p<0.05, " p<0.01$

\section{Scallop growth}

Scallop growth, as measured by mean shell height, was slow at all 3 depths until late August when the growth rate started to increase (Fig. 9a). The increase in average scallop tissue weight was similar at all 3 depths until late August when the growth rate at $50 \mathrm{~cm}$ and particularly at $300 \mathrm{~cm}$ increased over the next 2 mo (Fig. 9b). Substantial growth in shell height was found to occur over the winter months from December 1991 to April 1992 when ice conditions made it impossible to sample the seston. In April 1992 mean shell heights ranged from $60.5 \pm 6.0 \mathrm{~mm}$ at $20 \mathrm{~cm}$ to $64.5 \pm 4.0 \mathrm{~mm}$ at $300 \mathrm{~cm}$. Scallop tissue weight increased $20 \%$ over the same period.

\section{DISCUSSION}

\section{Total lipids and lipid classes}

The average concentrations of total lipids (Table 1) were lower than those in inlets in neighbouring Nova erols ranged from 34 to 58; however, all samples were strongly dominated by molecular species with 48 to 54 carbons. $\mathrm{A} \mathrm{C}_{48}$ triacylglycerol could have a fatty acid carbon number distribution such as 16:16:16, while a $\mathrm{C}_{54}$ triacylglycerol could have one of 18:18:18. $\mathrm{C}_{16}$ and $\mathrm{C}_{18}$ fatty acids dominated in the neutral lipids (Table 2). There seemed to be a shift towards higher carbon number TG as the season progressed.

In a comparison between the total triacylglycerol concentration determined by GC on the non-polar column and the total triacylglycerol concentration determined using the Iatroscan, the 2 totals were correlated ( $r=0.63, p<0.02, n=15$ ) and there was no significant difference between the means ( $p=0.08$ ). However, on average the GC gave a lower total than the Iatroscan, presumably through loss of polyunsaturated triacylglycerols.

Fig. 9. Placopecten magellanicus. Seasonal variations in (a) shell height (mean \pm SEM, $n=10$ to 70 ) and (b) tissue dry mass $(n=10)$ for giant scallops collected from 3 different water depths in South Broad Cove
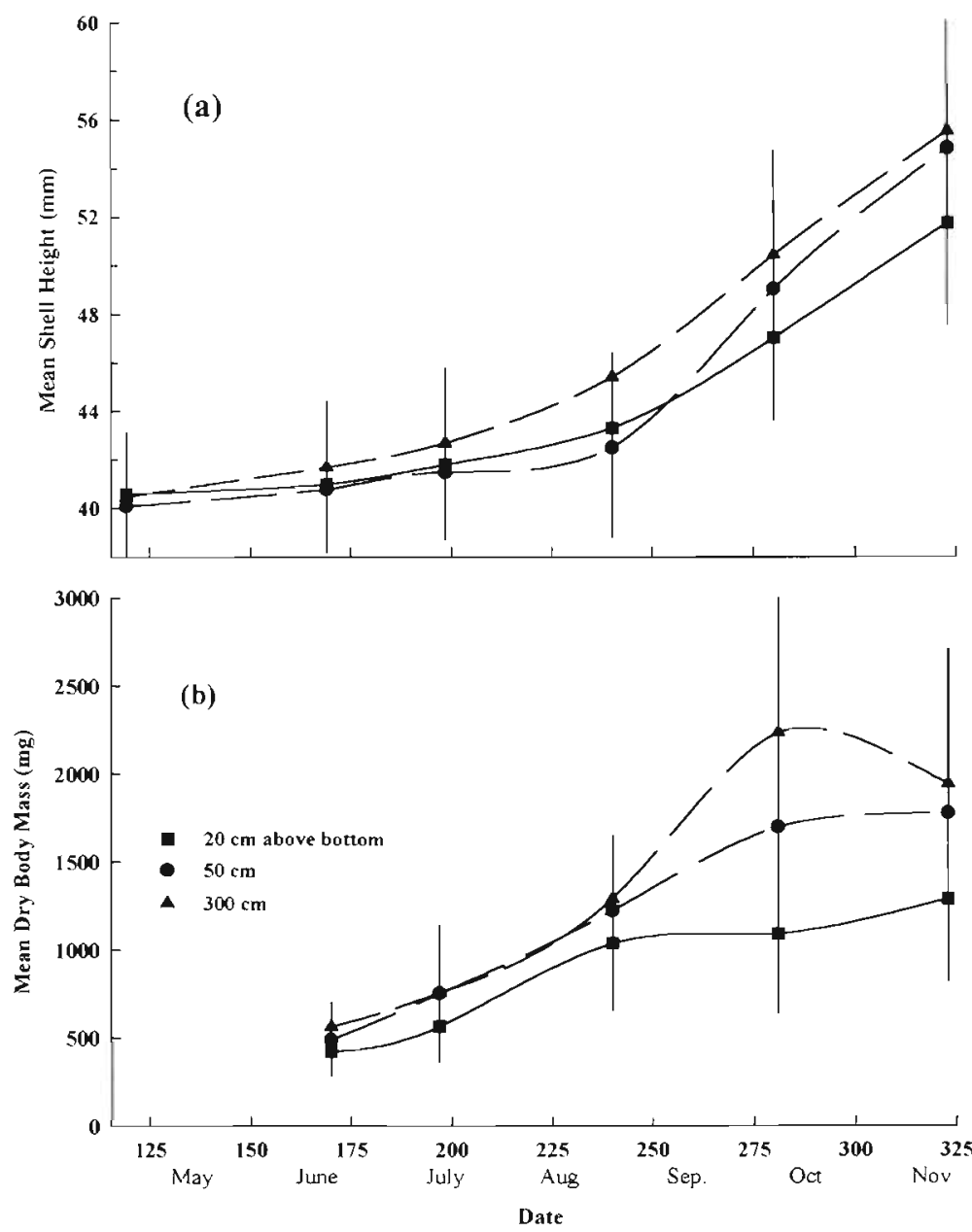
Scotia from March to August (Parrish 1987, Goutx 1988, Parrish et al. 1992b). Total lipid concentrations (Table 1) were 13 to $64 \%$ of the averages of $116 \pm 27$ and $400 \pm 54 \mathrm{\mu g} \mathrm{l}^{-1}$ measured in the vicinity of Halifax after the spring bloom (Parrish 1987, Goutx 1988) and 63 to $89 \%$ of the total measured in Ship Harbour, a mussel aquaculture site, in August 1989 (Parrish et al. 1992b). However, the average proportions of the lipid classes are quite similar to those measured in inlets in Nova Scotia except that the proportions of hydrocarbons and phospholipids are generally higher, and those of free fatty acids generally lower in South Broad Cove than in Nova Scotian inlets. Nonetheless, hydrocarbon concentrations are generally lower (Parrish 1987, Goutx 1988, Parrish et al. 1992b). The significantly higher concentration at $20 \mathrm{~cm}$ above bottom suggests hydrocarbons may be associated with resuspended material. Since hydrocarbons are not efficiently used or stored by most organisms (e.g. Meyers \& Ishiwatari 1993), it is possible that high proportions in near bottom suspended matter reflect preferential use of other lipid classes. However, hydrocarbon concentrations in Table 1 should be taken as maximal values because of the difficulty of avoiding hydrocarbon contamination.

Phospholipids are essential components of membranes, while free fatty acids are often associated with hydrolysis or breakdown of acyl lipid classes. Thus, the higher average proportions of membrane lipids and the lower proportions of the breakdown indicator (Table 1), suggest a more healthy, actively growing microbial community in South Broad Cove than in the Nova Scotia samples (Parrish 1987, Goutx 1988, Parrish et al. 1992b).

An index to indicate the degree of hydrolysis has been proposed by Weeks et al. (1993) which they term the hydrolysis index (HI). They define it as:

$$
\mathrm{HI}=\frac{\text { (free fatty acids }+ \text { alcohols })}{\text { (total non-polar acyl lipids }+ \text { products })} \times 100
$$

The average HI values for South Broad Cove range from $26.5 \pm 4.8$ at $300 \mathrm{~cm}$ to $33.2 \pm 5.6$ at $50 \mathrm{~cm}$, with
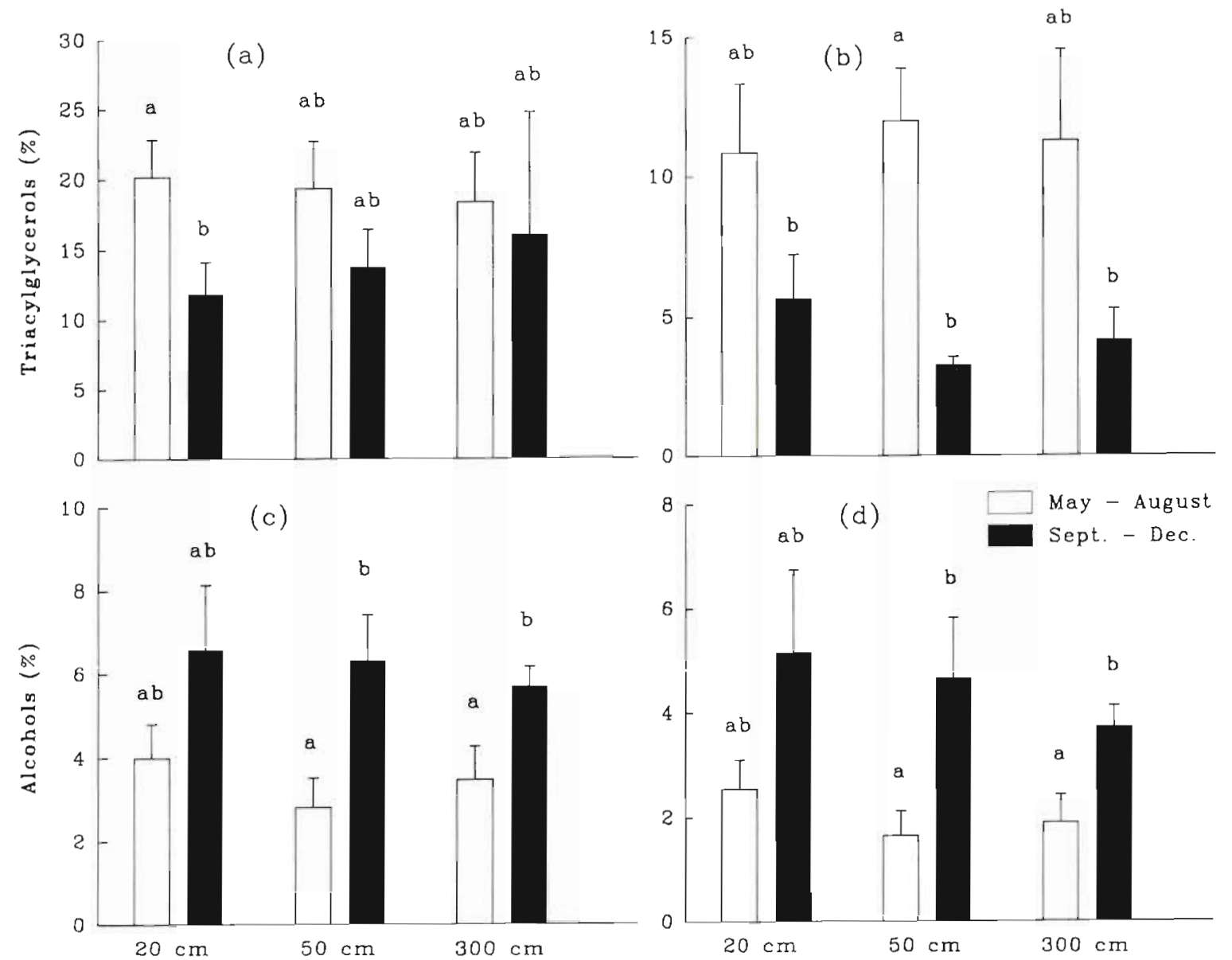

Fig. 10. Seasonal averages in lipid class proportions for 3 depths in South Broad Cove in 1991. Means not sharing the same letter are significantly different $(p<0.05)$. (a) Total triacylglycerols, (b) more saturated tnacylglycerol, (c) total alcohols (aliphatıc + alicyclic), (d) aliphatic alcohol 
medians in the range 28 to 31 . Weeks et al. (1993) found median $\mathrm{HI}$ values in the range 15 to 44 in the North Atlantic in June. The magnitude of their HI values was related to mesozooplankton biomass and grazing rates, to phaeophorbide concentrations, and to the mole percentage of phaeopigments relative to chl a. Since the median HI values for South Broad Cove are in the middle of the values given by Weeks et al. (1993) there is an indication of inefficient zooplankton feeding during the year in South Broad Cove.

We have also calculated an alternative index (Table 1) based on that of Weeks et al. (1993) which we define as

$$
\text { LI }(\%)=\frac{(\text { free fatty acids }+ \text { free alcohols })}{(\text { total acyl lipids }+ \text { free alcohols })} \times 100
$$

For the samples from South Broad Cove this index is strongly correlated with that of Weeks et al. (1993). However, this lipolysis index differs from theirs in that it takes into account all sources of hydrolysis products, polar and non-polar, since the only classes missing in the denominator are hydrocarbons and sterols. In South Broad Cove, polar lipids accounted for 40 to $50 \%$ of the lipids (Table 1) and are thus a very large potential source of free fatty acids.

While the proportions of total triacylglycerols (Fig. 10a) are similar to those measured during a spring bloom in Nova Scotia (Parrish 1987), the nature of the triacylglycerols and the timing of maxima in the time course were different in South Broad Cove. The triacylglycerol chromatographic peaks were invariably split into less polar and more polar subcomponents (Fig. 7), a phenomenon rarely observed previously. The splitting of the triacylglycerol peak into 2 components occurs in analyses of algal extracts because of the presence of triacylglycerol molecular species with very different degrees of unsaturation (Parrish et al. 1992a). It is possible that peak splitting was less common in previous studies because analysis conditions were not optimized to observe this separation.

Maxima in time courses of polyunsaturated and more saturated triacylglycerols occurred at different times (Fig. 5c), and neither occurred immediately after the spring diatom bloom as observed previously (Parrish 1987). Our sampling frequency around the diatom increase was not high enough to observe changes in lipid metabolism within the spring diatoms, but we were able to clearly see the effects on the seston triacylglycerol composition of successive species in different seasons. Resuspension of Gyrosigma spp. seemed to have been responsible for a large input of polyunsaturated triacylglycerol to the water column, while later on in the year a bloom of microzooplankton and nanoflagellates seemed to have caused a large input of more saturated triacylglycerol.

\section{Fatty acids in neutral and polar lipids}

Saturated fatty acids were proportionally the largest contributor to the neutral and polar lipids in the samples from South Broad Cove (Table 2). Saturated fatty acids were also the major contributors to the total lipids in samples taken from March to August in inlets on the Atlantic coast of Nova Scotia (Mayzaud et al. 1989, Parrish et al. 1992b), including an inlet used for bivalve culture. One saturated fatty acid, 16:0, was the single largest contributor in these samples, as it was in the total lipids of the samples from the Nova Scotia inlets. The total monoenoic fatty acids are present in similar amounts in the 2 fractions and in comparison with the Nova Scotia samples. The major component was $18: 1 \omega 9$ which was also a prominent contributor to the Nova Scotia samples.

The total dienoic fatty acids were present in much higher proportions than in Nova Scotia, but the major component, $18: 2 \omega 6$, was the same in both locations. The trienes consisted entirely of 18:3 133 in South Broad Cove; this polyunsaturated fatty acid was a major triene in Nova Scotia as well. Similarly, the desaturation product of this fatty acid, 18:4 $\omega 3$, was the major representative of the tetraenoic fatty acids in Newfoundland and Nova Scotia. However, 20:4 66 was present at unusually high levels in the neutral lipids in South Broad Cove by comparison with the total lipids in extracts from Nova Scotia. Sargent et al. (1987) suggested that this fatty acid, which can be rich in a variety of benthic animals, originates in benthic eucaryotic organisms such as protozoa. Alternatively, this fatty acid may originate in terrestrial or freshwater organisms, given the proximity to shore of our sampling location. The mean of $2.0 \%$ (Table 2 ) is close to the $2.3 \%$ of $20: 4 \omega 6$ found in the total lipids at a freshwater station in a stratified estuary (Scribe et al. 1991). Similarly, the $\sum \omega 6 / \sum \omega 3$ ratio in the neutral lipids was unusually high but close to the ratio of 1.2 which can be calculated for freshwater particles in the estuary (Scribe et al. 1991). The $\sum \omega 6 / \sum \omega 3$ ratio in the polar lipids, however, was similar to those which can be calculated for seawater samples from the stratified estuary.

Neutral lipid fatty acids (Table 3 ) and polar lipid fatty acids (Table 4) showed significant correlations with proportions of microplankton in the $50 \mathrm{~cm}$ samples. It is notable that except in the case of centric diatoms and bacteriovores, none of the fatty acids shows the same correlations in both fractions. Some of the correlations are in agreement with fatty acid markers of species or groups of species previously identified in total lipid extracts in the literature. For example, 14:0 and the ratio 16:1/16:0 (Tables $3 \& 4: r>0.62, p<0.05$ ) have been identified as being characteristic of diatoms (Claustre et al. 1988/1989). While these diatom mark- 

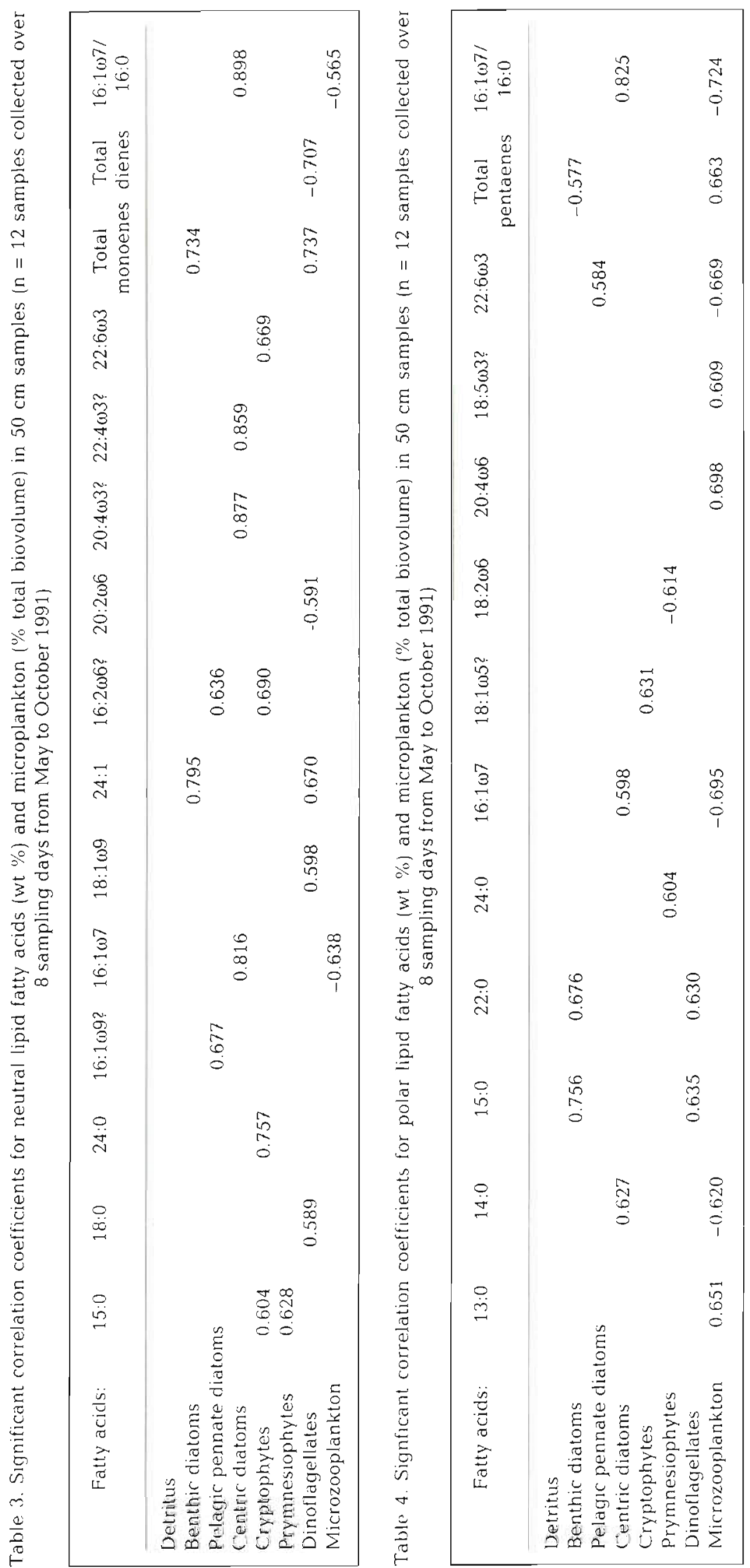

ers show up clearly in our correlation analysis, the seasonal averages are actually quite low (Table 2) presumably reflecting large contributions of $16: 0$ by other species at different times during the year (Fig. 3). When all the diatom groups were combined, strong correlations with $16: 1 / 16: 0$ remained ( $r>0.86$, $\mathrm{p}<0.01$ ).

Correlations with some of the polyunsaturated fatty acids in the polar lipids were also consistent with literature data from total lipids. For instance, 18:5 (Table 4: $r=0.609, p<0.05$ ) has been found to be concentrated in tintinnids, which are bacteriovores (Claustre et al. $1988 / 1989$ ). Given the proximity of the samples to the seabed, the highly significant $(p<0.02)$ positive correlation of 20:466 with microzooplankton (Table 4) is in accord with benthic protozoa being a likely source of $\omega 6$ polyunsaturated fatty acids in benthic food webs (Sargent et al. 1987). The naked ciliate Mesodinium rubrum, which was particularly abundant in these samples may have been a major contributor. Some species of Mesodinium have been found in the sediment substrata (Borror 1973). However, the high concentrations at depth could also be part of their water column migration pattern

Correlations with $15: 0$ and $22: 603$ in the neutral lipids (Table 3 ) also agree with the literature. The flagellates Chromulina (Chrysophyceae which are closely related to the Prymnesiophyceae) and Cryptomonas (Cryptophyceae) were found to have high contents of 15:0 compared to other flagellates and to several species of Cyanophyceae and Chlorophyceae (Ahigren et al. 1992). Sargent et al. (1987) stated that 22:603 is also particuIarly abundant in Cryptophyceae. Cryptophytes rank in the top $25 \%$ in terms of 22:6w3 content among 37 species of marine microalgae in 10 taxonomic classes (Volkman et al. 1989, Viso \& Marty 1993). Such correlations with fatty acids in the neutral lipids suggest that in addition to membrane fatty acids (Sargent et al. 1987), fatty acids in storage may also provide useful biomarkers. 
There were several significant negative correlations between particular fatty acids and microplankton, but most occurred with fatty acids in the polar lipids (Table 4) and most occurred with microzooplankton. The consistent negative correlation between the 16:1 $107 / 16: 0$ ratio characteristic of diatoms (Tables $3 \&$ 4) and microzooplankton presumably is a consequence of the different timing of blooms of these organisms. The lack of any correlations with detritus (Tables $3 \& 4$ ) may reflect the ubiquity of the sources of this material.

There were also several biomarker fatty acids described in the literature (Sargent et al. 1987) that did not show any significant correlations in our data set. For example, $18: 503$ has been shown to be a useful marker of dinoflagellates and food web related organisms (Mayzaud et al. 1976), but the only significant correlation we found was with microzooplankton (Table 4). 18:5 33 has also been associated with some prymnesiophytes (Volkman et al. 1981) and some prasinophytes (Dunstan et al. 1992). Prasinophytes were not a significant contributor to our samples but prymnesiophytes accounted for an average of $12 \%$ of the biovolume at $50 \mathrm{~cm}$. However, combining prasinophytes with dinoflagellates still did not give a significant correlation with 18:5 13 . Similarly, an abundance of $16: 1 \omega 7,16: 0,20: 4 \omega 6$, and $20: 5 \omega 3$ has been used to indicate that diatoms were a major contributor of fatty acids to a surface sediment (Volkman et al. 1980). In our data set 16:1 $1 \omega 7$ was correlated with centric diatoms (Tables $3 \& 4$ ) and with all 3 groups of diatoms combined $(r>0.64, p<0.05)$ but the other 3 acids gave no significant correlations with the diatom groups individually or combined. The extent to which differences between our data and the literature are functions of our having subdivided our lipids before analysis, our small sample size, our geographic location, or the multiplicity of sources for some biomarkers, awaits the results of further studies in other bays around Newfoundland.

\section{Scallop growth in relation to seston composition}

Scallop growth is a complicated function of food and temperature. Types of food particles such as phytoplankton, detritus and resuspended matter are major components of the variance in food quality in the field through variation in their carbon and nitrogen contents (Grant \& Cranford 1991). Laboratory experiments have shown specific organic compounds appear to be more critical than others in supporting bivalve growth. Thompson \& Harrison (1992) found that growth rates of larvae of the Pacific oyster were less dependent on algal protein content and more dependent on the content of carbohydrates and especially of certain fatty acids.
In South Broad Cove, scallops located $300 \mathrm{~cm}$ above bottom grew best over the year (Fig. 9), despite the seston at that depth having the lowest concentrations of microplankton (Fig. 2), chl a, AFDW and total lipids. In addition, scallops grew better in the latter part of the sampling period when concentrations of each of the measured chemical components of the seston were lower by comparison with the first half of the sampling period. This suggests that there is a factor other than simply the availability of food or even high energy compounds (Figs. 5a \& 10a, b) that is important to the growth of scallops in South Broad Cove. Temperature would be a likely candidate; however, the continued growth of the scallops through the winter when the temperature dropped below $0^{\circ} \mathrm{C}$ would suggest this is not the dominant factor. One important chemical factor could be the essential fatty acid 22:6w3 which on average was present at quite low concentrations (Table 2), although it showed a distinct seasonal pattern (Fig. 8). This polyunsaturated fatty acid was the major fatty acid in the adductor muscle in scallops growing in a similar environment (Napolitano et al. 1992). Thompson \& Harrison (1992) found that increases in 22:6w3 were consistently associated with improved growth and survival of oyster larvae, with an increase of the content of $22: 603$ from $1 \%$ to $3 \%$ of the total fatty acids being beneficial. This increase is almost identical to that observed in South Broad Cove (Fig. 8). Our correlation analysis (Table 3) suggests cryptophytes ( $p<$ 0.02 ) were the major supplier of this fatty acid to scallops in South Broad Cove. Cryptophytes may have been a preferred food for these scallops, since bivalves have been shown to preferentially absorb a cryptomonad flagellate when a mixed diet is ingested (Shumway et al. 1985).

Acknowledgements. We thank E. Ward, J. P. A. Gardner, M. Miller and G. Bacon for sampling and extractions, A. Lau for lipid class analyses and Z. Yang for fatty acid analyses. This work was funded through NSERC grants to C.C.P., B.A.MacD., and R. J. Thompson and through the Ocean Production Enhancement Network (OPEN), one of the 15 Centres of Excellence funded by the Government of Canada. This is Ocean Sciences Center contribution no. 249.

\section{LITERATURE CITED}

Ackman RG (1986) WCOT (capillary) gas-liquid chromatography. In: Hamilton RJ, Rossell JB (eds) Analysis of oils and fats. Elsevier, London, p 137-206

Ahlgren G, Gustafsson IB, Boberg M (1992) Fatty acid content and chemical composition of freshwater microalgae. J Phycol 28:37-50

Borror AC (1973) Marine flora and fauna of the northeastern United States. Protozoa: Ciliophora. NOAA Technical Report NMFS CIRC-378. Washington, DC, p 44

Clarke A, Holmes LJ, Hopkins CCE (1987) Lipid in an arctic food chain: Calanus, Bolinopsis, Beroe. Sarsia 72:41-48 
Claustre H, Marty JC, Cassiani L, Dagaut J (1988/1989) Fatty acid dynamics in phytoplankton and microzooplankton communities during a sprnng bloom in the coastal Ligurian Sea: ecological implications. Mar microb Food Webs 3: $51-66$

Dunstan GA, Volkman JK, Jeffrey SW, Barrett SM (1992) Biochemical composition of microalgae from green algal classes Chlorophyceae and Prasinophyceae. 2. Lipid classes and fatty acids. J exp mar Biol Ecol 161 $115-134$

Goutx MM (1988) Particulate lipid survey in the Bedford Basin (Nova Scotia) using thin-layer chromatography with flame ionization detection. Comparison of hydrocarbons data with gas chromatography analyses. Mar environ Res $26: 83-95$

Grant J, Cranford PJ (1991) Carbon and nitrogen scope for growth as a function of diet in the sea scallop Placopecten magellanicus. J mar biol Ass UK 71:437-450

Gurr MI, Harwood JL (1991) Lipid biochemistry. An introduction. Chapman-Hall, London, p 173-181

Hasle GR (1978) Using the inverted microscope. In: Sournia A (ed) Phytoplankton manual. UNESCO, Paris, p 191-201

Joseph JD (1982) Lipid composition of marine and estuarine invertebrates. Part II: Mollusca. Prog Lipid Res 21. $109-153$

Mayzaud P, Chanut JP, Ackman RG (1989) Seasonal changes of the biochemical composition of marine particulate matter with special reference to fatty acids and sterols. Mar Ecol Prog Ser 56:189-204

Mayzaud P, Eaton CA, Ackman RG (1976) The occurrence and distribution of octadecapentaenoic acid in a natural plankton population. A possible food chain index. Lipids 11:858-862

Meyers PA, Ishiwatari R (1993) Lacustrine organic geochemistry - an overview of indicators of organic matter sources and diagenesis in lake sediments. Org Geochem $20: 867-900$

Napolitano GE, MacDonald BA. Thompson RJ, Ackman RG (1992) Lipid composition of eggs and adductor muscle in giant scallops (Placopecten magellanicus) from different habitats. Mar Biol 113:71-76

Parrish CC (1987) Time series of particulate and dissolved lipid classes during spring phytoplankton blooms in Bedford Basin, a marine inlet. Mar Ecol Prog Ser 35: $129-139$

Parrish CC, Bodennec G, Gentien P (1992a) Separation of polyunsaturated and saturated lipids from marine phytoplankton on silica gel-coated Chromarods. J Chromat 607 $97-104$

Parrish CC, Bodennec G, Macpherson EJ, Ackman RG (1992b) Seawater fatty acids and lipid classes in an urban and a rural Nova Scotia inlet. Lipids 27:651-655

This article was submitted to the editor
Roessler PG (1990) Environmental control of glycerolipid metabolism in microalgae: commercial implications and future research directions. J Phycol 26:393-399

Rott $E$ (1981) Some results from phytoplankton counting intercalibrations. Schweiz Z Hydrol 43/1:34-62

Saliot A, Laureillard J, Scribe P, Sicre MA (1991) Evolutionary trends in the lipid biomarker approach for investigating the biogeochemistry of organic matter in the marine environment. Mar Chem 36:233-248

Sargent JR, Parkes RJ, Mueller-Harvey I, Henderson RJ (1987) Lipid biomarkers in marine ecology. In: Sleigh MA (ed) Microbes in the sea. Wiley and Sons, New York, $p$ $119-138$

Scribe P, Fillaux J, Laureillard J, Denant V, Saliot A (1991) Fatty acids as biomarkers of planktonic inputs in the stratified estuary of the Krka River, Adriatic Sea: relationship with pigments. Mar Chem 32:299-312

Shumway SE, Cucci TL, Newell RC, Yentsch CM (1985) Particle selection, ingestion, and absorption in filter-feeding bivalves. J exp mar Biol Ecol 91:77-92

Thompson PA, Harrison PJ (1992) Effects of monospecific algal diets of varying biochemical composition on the growth and survival of Pacific oyster (Crassostrea gigas) larvae. Mar Biol 113:645-654

Utermöhl H (1958) Zur Vervollkommnung der quantitativen Phytoplankton-Methodik. Mitt int Verein theor angew Limnol 9:1-38

Venrick EL (1978) How many cells to count? In: Sournia A (ed) Phytoplankton manual. UNESCO, Paris, p 167-180

Viso AC, Marty JC (1993) Fatty acids from 28 marine microalgae. Phytochem 34:1521-1533

Volkman JK, Jeffrey SW, Nichols PD, Rogers GI, Garland CD, (1989) Fatty acid and lipid composition of 10 species of microalgae used in mariculture. J exp mar Biol Ecol 128 $219-240$

Volkman JK, Johns RB, Gillan FT, Perry GJ, Bavor HJ Jr (1980) Microbial lipids of an intertidal sediment. I. Fatty acids and hydrocarbons. Geochirn cosmochim Acta 44: $1133-1143$

Volkman JK, Smith DJ, Eglinton G, Forsberg TEV, Corner EDS (1981) Sterol and fatty acid composition of four marine haptophycean algae. J mar biol Ass UK 61:509-527

Weeks A, Conte MH, Harris RP, Bedo A, Bellan I, Burkill PH, Edwards ES, Harbour DS, Kennedy H, Llewellyn C, Mantoura RFC, Morales CE, Pomroy AJ, Turley CM (1993) The physical and chemical environment and changes in community structure associated with bloom evolution: the Joint Global Flux Study North Atlantic Bloom Experiment. Deep Sea Res II 40:347-368

Yentsch CS, Menzel DW (1963) A method for the determination of phytoplankton, chlorophyll, and phaeophytin by fluorescence. Deep Sea Res 10:221-231

Manuscript first received: November 24, 1994

Revised version accepted: June 7, 1995 